\title{
Exposing the Stealth Candidate: Disclosure Statutes After McIntyre $v$ Ohio Elections Commission
}

\author{
Thomas H. Dupree, Jr.†
}

Campaigns for elective office are often won or lost in the living rooms of America. Candidates wage war over the airwaves, attacking opponents' beliefs, voting records, or character. ${ }^{1}$ In response, the majority of states has sought to enrich the quality of political debate-and perhaps even preserve a shred of civility-by enacting disclosure statutes that require sponsors of political advertisements to identify themselves on screen. ${ }^{2}$ Propo-

$\dagger$ B.A. 1992, Williams College; J.D. Candidate 1997, The University of Chicago.

1 See generally Stephen Ansolabehere and Shanto Iyengar, Going Negative: How Political Advertisements Shrink and Polarize the Electorate 1-16 (Free Press 1995). See also Larry J. Sabato, The Rise of Political Consultants: New Ways of Winning Elections 117 (Basic Books 1981) (Television is voters' primary source of campaign information.).

2 Thirty-one states and the federal government have enacted such statutes. See Brief of Amici Curiae for the States of Tennessee, et al, in Support of Respondent at 1, Appendix 1, McIntyre v Ohio Elections Commission, 115 S Ct 1511 (1995) (No 93-986). Alabama, for example, requires disclosure in television and radio commercials. See Ala Code § 1722A-12 (1995), which provides:

Any paid political advertisement... broadcast on any electronic media shall be clearly identified or marked as a paid advertisement. It shall be unlawful for any person, candidate, principal campaign committee or other political committee to broadcast ... [any] political advertisement, without a notice... broadcast at the beginning or end of a radio or television spot, stating that the communication was a paid advertisement and giving the identification of the person, principal campaign committee or other political committee that paid for, or otherwise authorized such communication.

See also Wash Rev Code Ann $\S$ 42.17.510(1) (West 1991 \& Supp 1996) ("All radio and television political advertising, whether relating to candidates or ballot propositions, shall include the sponsor's name."). Congress has outlawed anonymous communications in campaigns for federal office:

Whenever any person makes an expenditure for the purpose of financing communications expressly advocating the election or defeat of a clearly identified candidate, or solicits any contribution through any broadcasting station... such communication-(1) if paid for and authorized by a candidate, an authorized political committee of a candidate, or its agents, shall clearly state that the communication has been paid for by such authorized political committee.

2 USC § 441d(a) (1994). 
nents argue that by removing the cloak of anonymity, disclosure statutes foster accountability, deter false or libelous statements, and provide voters with information helpful in evaluating an advertisement's content. ${ }^{3}$

Yet the constitutionality of these statutes has been cast into doubt. The Supreme Court, in McIntyre v Ohio Elections Commission, ${ }^{4}$ invalidated a broad provision of the Ohio Elections Code that banned all anonymous political leafletting. ${ }^{5}$ Margaret McIntyre had challenged her one-hundred-dollar fine for distributing unsigned flyers opposing a proposed local school tax. ${ }^{6}$ Finding that Ohio's interests did not justify the disclosure statute's burden on "core political speech," and noting the "honorable tradition" of anonymous political speech in American history, the Court held that the statute violated the First Amendment. ${ }^{7}$

McIntyre threatens to cut a broad swath through state election codes. The ruling "cast[s] doubt on the election laws of nearly every state" and "appears likely to prompt a new round of challenges to the disclosure requirements contained in Federal and numerous state election laws." B But the precise scope of McIntyre is far from clear. The Court offered little guidance as to

3 See generally Developments In the Law-Elections, 88 Harv L Rev 1111, 1286-91 (1975) (reviewing history and purposes of state disclosure statutes). Courts have invoked these and other justifications in upholding disclosure statutes against First Amendment challenges. See text accompanying notes $45-48$.

4115 S Ct 1511 (1995).

5 Ohio Rev Code Ann § 3599.09(A) (Baldwin 1995) provides:

No person shall write ... a notice, placard, dodger, advertisement, sample ballot, or any other form of general publication which is designed to promote the nomination or election or defeat of a candidate, or to promote the adoption or defeat of any issue, or to influence the voters in any election ... unless there appears on such form of publication in a conspicuous place... the name and residence or business address of the chairman, treasurer, or secretary of the organization issuing the same, or the person who issues, makes, or is responsible therefor.

6 See McIntyre, $115 \mathrm{~S}$ Ct at 1514.

7 Id at 1518-19, 1524.

8 Linda Greenhouse, Justices Allow Unsigned Political Fliers, NY Times A20, A20 (Apr 20, 1995). Prior to the Court's ruling, a broad coalition of state and local governments warned that invalidation of Ohio's statute would threaten existing state election codes. "[T]he invalidation of Ohio's source identification requirement could not only jeopardize source identification laws in many other States, but could also call into question other election disclosure laws which limit anonymity in campaign contributions, expenditures, and communications." Brief of the Council of State Governments, et al, as Amici Curiae in Support of Respondent at 2, McIntyre $v$ Ohio Elections Commission, $115 \mathrm{~S}$ Ct 1511 (1995) (No 93-986). The coalition characterized Ohio's law as a garden-variety campaign disclosure requirement. Id at 25 . 
the decision's applicability to statutes that regulate a narrower class of speakers-such as candidates for public office-or a communications medium other than print. ${ }^{9}$ More broadly, the Court failed to illuminate a clear boundary between permissible and impermissible state regulation of political speech. After emphasizing the considerable benefits of anonymous political speech entering the marketplace, the Court then conceded that "a State's enforcement interest might justify a more limited identification requirement ...."10 The dissent accused the majority of failing to establish a clear rule of law for reviewing disclosure statutes, predicting that "[i]t may take decades to work out the shape of this newly expanded right-to-speak-incognito ...."11

The puzzlement of state election officials in the wake of McIntyre suggests that the dissent's forecast was accurate. State officials from Pennsylvania to Alaska have openly questioned the holding's sweep. ${ }^{12}$ Similarly, political commentators have speculated about the decision's applicability to television advertising. ${ }^{13}$ And candidates themselves have defied state disclosure laws, citing McIntyre in their defense. ${ }^{14}$ The decision's many

9 Notably, the Court did not address $\S 3599.09$ (B) of the Ohio Code, which contains a parallel prohibition of anonymous political speech broadcast on television or radio. See note 78 and accompanying text.

${ }^{10}$ McIntyre, $115 \mathrm{~S} \mathrm{Ct}$ at 1522 . Justice Ginsburg, in a concurring opinion, similarly highlighted her concern that a broad reading of McIntyre might establish a right to anonymity bordering on the absolute, thereby foreclosing state regulation under any circumstances: "We do not thereby hold that the State may not in other, larger circumstances, require the speaker to disclose its interest by disclosing its identity." Id at 1524 (Ginsburg concurring).

11 Id at 1535 (Scalia dissenting).

12 See, for example, Sean Connolly and Peter J. Shelly, Republican staff won't be charged: Ruling OK's anonymity, Harrisburg Patriot B1 (May 6, 1995) (available in Westlaw at 1995 WL 5062175) (Pennsylvania Attorney General unsure of decision's scope, but believes that " $[t]$ he Supreme Court has changed in one fell swoop the way campaigns work and have worked for years" and questions whether the opinion could extend to campaign advertisements.); Stan Jones, Alaska weighs ruling: Political messages could be nameless, Anchorage Daily News C-1, C-3 (Apr 22, 1995) (Chairman of Alaska Public Offices Commission unsure of decision's applicability to Alaska statute.).

${ }^{13}$ See Editorial, Anonymous Electioneering, Wash Post A18, A18 (Apr 24, 1995) ("Justice Scalia is probably correct in predicting decades of litigation testing this ruling. Will political advertisers in the mass media claim a right to remain anonymous?"). Most political professionals fear the decision will encourage negative campaigning. The President of the American Association of Political Consultants opined, "I'm a real First Amendment man, but I think they have opened Pandora's box." David Broder, Bungled By the High Court, Wash Post C7, C7 (May 7, 1995).

14 For example, within a month of the Court's decision, a candidate for town supervisor in Palmer, Pennsylvania disregarded a state law prohibiting anonymous political communication. He told a reporter that McIntyre protected his action. See Dennis Kelly, Palmer candidate defends political materials, Allentown Morning Call B4, B4 (May 16, 
unresolved questions-reflected in the confusion of those who administer (and those who are subject to) the laws-indicate that lower courts will face considerable uncertainty in applying McIntyre to their own state disclosure statutes. ${ }^{15}$

This Comment addresses the decision's applicability to an important and ubiquitous provision of state election codesdisclosure requirements for televised political advertisements. The Comment advocates a narrow interpretation of McIntyre and argues that laws prohibiting anonymous campaign commercials are not unconstitutional. Section I examines the tension between First Amendment goals and a state's interest in regulating its elections, paying particular attention to judicial attempts to reconcile the two when reviewing disclosure statutes. Section II discusses and critiques McIntyre and identifies the ambiguities it leaves for lower courts. Finally, Section III applies McIntyre to the context of televised speech by political candidates and argues that this type of speech differs in constitutionally significant ways from the speech protected by McIntyre. The Comment concludes that state disclosure laws, narrowly tailored to include only candidates or their agents communicating via broadcast media, remain constitutional after McIntyre.

\section{Regulating Election-Related SpeEch}

Election-related speech restrictions pose tough questions because they implicate conflicting interests. On one side stands the First Amendment, which has its "fullest and most urgent application precisely to the conduct of campaigns for political office."16 Courts have consistently recognized the First

1995).

15 Two courts have applied McIntyre to disclosure statutes and reached opposite conclusions. Yet the difference in scope of the contested statutes-one was limited to fund raising and the other swept in all anonymous advertisements relating to elections and ballot initiatives-precludes confident prediction about post-McIntyre jurisprudence. The Second Circuit, in FEC v Survival Education Fund, Inc., 65 F3d 285, 295-98 (2d Cir 1995), upheld a federal law requiring disclosure by groups that solicit contributions even if the solicitation includes speech about political candidates. The court found that the state's interest in preventing a contributor from mistakenly donating to a cause he does not support is sufficient to overcome a First Amendment challenge. Id at 296-97. In contrast, a Louisiana court of appeals, in State $v$ Moses, 655 S2d 779, 782 (La Ct App 1995), struck down a sweeping state law that prohibited all anonymous communications relating to candidate elections or ballot propositions. For a discussion of these cases, see text accompanying notes 68-71.

${ }_{16}$ Monitor Patriot Co. $v$ Roy, 401 US 265, 272 (1971). See also Eu v San Francisco County Democratic Central Committee, 489 US 214, 222-33 (1989) (discussing First Amendment challenges to election codes). 
Amendment's role in creating and preserving a free and unfettered debate over politics and the qualifications of candidates for office. ${ }^{17}$ Disclosure statutes impose a burden on the speaker's First Amendment rights because they regulate the content of his speech, forcing him to reveal information that he might otherwise keep hidden. Moreover, courts have appreciated the particular importance of protecting political speech that criticizes the government. ${ }^{18}$ By burdening a type of political communication often aimed at incumbents, disclosure statutes may frustrate antigovernment speech.

On the other side of the debate lies the states' interest in preserving the integrity and reliability of their elections. The Court has recognized that "as a practical matter, there must be a substantial regulation of elections if [elections] are to be fair and honest and if some sort of order, rather than chaos, is to accompany the democratic processes." ${ }^{19}$ State regulation of elections encompasses not only the physical act of voting (and the associated time, place, and manner restrictions), but also regulation

17 See, for example, Mills $v$ Alabama, 384 US 214, 218-19 (1966) (The purpose of the First Amendment is to protect free discussion of public affairs, including discussions of individual candidates for office.). See also New York Times Co. v Sullivan, 376 US 254, 270 (1964) (The First Amendment reflects a "profound national commitment to the principle that debate on public issues should be uninhibited, robust, and wide-open.").

IB "Freedom of expression has particular significance with respect to government because "[i]t is here that the state has a special incentive to repress opposition and often wields a more effective power of suppression." First National Bank of Boston $v$ Bellotti, 435 US 765, 777 n 11 (1978), quoting Thomas Emerson, Toward a General Theory of the First Amendment 9 (Random House 1966). See also Lillian R. BeVier, Money and Politics: A Perspective on the First Amendment and Campaign Finance Reform, $73 \mathrm{Cal} \mathrm{L} \operatorname{Rev} 1045$, 1076 (1985) (suggesting that regulation of the political process "might be a context warranting distrust of elected officials," raising the "systematic possibility that legislators will behave in self- rather than public-interested ways").

${ }_{19}$ Storer v Brown, 415 US 724, 729-37 (1974) (reviewing ballot restrictions in California Elections Code). See also Burdick v Takushi, 504 US 428, 434 (1992) ("[W] Then a state election law provision imposes only 'reasonable, nondiscriminatory restrictions' upon the First and Fourteenth Amendment rights of voters, 'the State's important regulatory interests are generally sufficient to justify' the restrictions."), quoting Anderson $v$ Celebrezze, 460 US 780, 788 (1983). But the Court has underscored that election regulations that burden speech rest on shaky constitutional ground:

Just as a State may take steps to ensure that its governing political institutions and officials properly discharge public responsibilities and maintain public trust and confidence, a State has a legitimate interest in upholding the integrity of the electoral process itself. But when a State seeks to uphold that interest by restricting speech, the limitations on state authority imposed by the First Amendment are manifestly implicated. 
aimed at combating fraud and corruption in the electoral process. Courts have often found a state's interest in regulating its own elections sufficient to justify minor restraints on election-related speech. $^{20}$

Litigants on each side of a case involving a disclosure statute can claim their own polestars. Parties seeking to invalidate the statute point to Talley $v$ California, in which the Court recognized the historic worth of anonymous speech. ${ }^{21}$ In contrast, parties seeking to uphold the statute cite Buckley $v$ Valeo, in which the Court affirmed a state's power to regulate its own elections by requiring disclosure of campaign contributors. ${ }^{22}$ Before considering McIntyre, which attempts to navigate the muddy middle ground between Talley and Buckley, this Section examines these two prior cases and then reviews the pre-McIntyre treatment of disclosure statutes in the lower courts.

\section{A. Talley: The Value of Anonymous Speech}

The seminal case reviewing restrictions on anonymous speech is Talley $v$ California, in which the Court struck down on First Amendment grounds a Los Angeles city ordinance that required handbills to bear the name and address of the person who prepared, distributed, or sponsored them. ${ }^{23}$ The plaintiff in Talley distributed leaflets urging a boycott of certain local merchants. ${ }^{24}$ Although the handbills were attributed to "National Consumers Mobilization," with an address provided, the plaintiff was charged with violating the ordinance because the leaflets did not bear the plaintiff's personal name or address. ${ }^{25}$ The Court

${ }^{20}$ Courts typically review with great deference election regulations that concern the physical act of voting, such as laws regulating conduct at the polls. See, for example, Burson v Freeman, 504 US 191, 193-95 (1992) (upholding Tennessee statute prohibiting political campaigning within one hundred feet of the polls on Election Day). The Court has also permitted states to prevent "party raiding"-the switching of blocs of voters from one party to the other in order to manipulate the other party's primary election-on grounds that the state may prevent distortion of its electoral process. Rosario $v$ Rockefeller, 410 US 752, 760-62 (1973).

21362 US 60, 64-65 (1960). See, for example, State $v$ North Dakota Education Association, 262 NW2d 731, 735-36 (ND 1978) (invoking Talley in striking down disclosure statute).

${ }_{22}^{22} 424$ US 1, 60-84 (1976) (per curiam). See, for example, Minnesota State Ethical Practices Board v NRA, 761 F2d 509, 512 (8th Cir 1985) (invoking Buckley in upholding disclosure statute).

${ }^{23} 362$ US at 65 .

24 Id at 61.

25 Id. The handbills charged the merchants with carrying products of manufacturers who discriminated against minorities. 
underscored the value of anonymous speech in enabling a persecuted group to criticize an oppressive majority practice, concluding that "[t]here can be no doubt that [ ] an identification requirement would tend to restrict freedom to distribute information and thereby freedom of expression."26 Finally, the Court hailed what it termed "the most constructive purposes" of anonymous speech, noting that anonymous pamphlets "have played an important role in the progress of mankind."27

Yet the Court carefully circumscribed its holding. After condemning the breadth of the ordinance, which regulated handbill distribution in any place and under any circumstance, the Court suggested that a more narrowly tailored ordinance might have withstood First Amendment scrutiny: "[W]e do not pass on the validity of an ordinance limited to prevent [fraud, false advertising, libel] or any other supposed evils."28 This caveat suggests that Talley is best read not as establishing a general right to anonymous speech, but as reminding state legislatures to tailor disclosure statutes narrowly to protect specific state interests. ${ }^{29}$

\section{B. Buckley: Minimal Restrictions on Speech Are Permissible}

Sixteen years after Talley-and two years after Watergate-the Court upheld a federal statute requiring disclosure of contributors to campaigns for federal office. ${ }^{30}$ In Buckley $v$ Valeo,

${ }^{28}$ Id at 64. Although the plaintiff did not allege any specific threats of physical harm that might result from disclosure, courts have generally been quite sensitive to this danger. See, for example, NAACP v Patterson, 357 US 449, 462 (1958) (invalidating a state disclosure statute based on the dangers of "economic reprisal, loss of employment, threat of physical coercion [or] other manifestations of public hostility").

${ }^{27}$ Talley, 362 US at 64-65. The Court noted that Thomas Paine and other Revolutionera writers, including the authors of the Federalist Papers, often wrote anonymously or under pseudonyms. See id at $62 \mathrm{n} 3$.

${ }_{28}$ Id at 64 .

20 This reading is generally supported by lower courts' interpretations of Talley. See, for example, People $v$ Duryea, 76 Misc 2d 948, 351 NYS2d 978, 993-97 (NY Sup Ct 1974) (voiding disclosure statute for overbreadth when the statute was not narrowly drawn to further the state's interest in preserving the integrity of its campaigns and elections).

${ }^{30}$ The statute at issue was the Federal Election Campaign Act of 1971, Pub L No 92 225, 86 Stat 3 (1972), amended by Pub L No 93-443, 88 Stat 1263 (1974), codified as amended at 2 USC $\S \S 431$ et seq (1976). The statute provided, in part, that federal campaign committees must disclose:

[T]he full name and mailing address (occupation and the principal place of business, if any) of each person who has made one or more contributions to or for such committee or candidate... within the calendar year in an aggregate amount or value in excess of $\$ 100$, together with the amount and date of such contributions. 
the Court acknowledged that disclosure statutes necessarily curtail free speech: a potential donor may be deterred from making a contribution (itself a form of speech) if he cannot do so anonymously. ${ }^{31}$ Yet in the Court's judgment, the benefits of such a law outweighed the costs. The Court found that disclosure furthered three substantial state interests: informing the electorate, preventing corruption of the political process, and helping detect violations of campaign finance laws. ${ }^{32}$ The city ordinance invalidated in Talley was distinguishable in that the federal disclosure requirements at issue in Buckley were more narrowly tailored: they represented the "least restrictive means" for achieving the government's interests. ${ }^{33}$

The Buckley Court concluded that slight infringements on the First Amendment rights of certain speakers, although deterring some potential speakers from speaking at all, nonetheless served larger First Amendment goals by providing voters with relevant information about a candidate. ${ }^{34}$ In this sense, the Court's intent was not to maximize the amount of speech that enters the public arena. Instead, the Court accepted a slight

2 USC $\S 434(b)(2)$. The statute also required private individuals to disclose independent expenditures made for communications advocating the election or defeat of candidates for federal office. 2 USC \& 434(e). Courts have relied on Buckley to uphold similar state schemes requiring disclosure of campaign contributors. See, for example, State $v$ Marshall, 633 P2d 227, 236 (Alaska 1981).

31424 US at 68.

32 Disclosure of contributors' identities (and the amount of their contributions) helps voters evaluate candidates and predict their future performance in office. Specifically, disclosure of contributors reveals a candidate's ideological leanings. Politicians recognize that accepting a contribution from the NRA or a gay rights group, for example, signals to the electorate that the candidate generally supports (or at least does not oppose) the group's goals. See id at 66-68. For a general discussion of the influence of money on political campaigns, see Herbert E. Alexander, Financing Politics: Money, Elections, and Political Reform (Cong Q 4th ed 1992).

${ }^{33}$ Buckley, 424 US at 68.

34 Disclosure statutes are "a reasonable and minimally restrictive method of furthering First Amendment values by opening the basic processes of our federal election system to public view." Id at 82 . This line of logic was echoed in First National Bank of Boston $v$ Bellotti, where the Court emphasized the informational interest that disclosure statutes served by assisting voters in evaluating the arguments placed before them, noting that "[i]dentification of the source of advertising may be required as a means of disclosure, so that the people will be able to evaluate the arguments to which they are being subjected." 435 US 765, $792 \mathrm{n} 32$ (1978). Despite these remarks, the precedential value of Bellotti in the disclosure-statute context is quite limited, since the constitutionality of such a statute was not before the Court. See McIntyre, $115 \mathrm{~S}$ Ct at 1522 . This unpleasant reality, however, has not deterred attorneys' talismanic invocations of the decision. See, for example, Brief of Amici Curiae for the States of Tennessee, et al, in Support of Respondent at 5-6 (cited in note 2) (using Bellotti to support state's interest in helping voters evaluate political arguments through disclosure requirements). 
reduction in the total quantity of speech in exchange for a higher quality. ${ }^{35}$

\section{Disclosure Statutes in the Lower Courts}

Prior to McIntyre, lower courts reached different conclusions concerning the constitutionality of disclosure statutes. This is not surprising: state disclosure statutes come in all shapes and sizes ${ }^{36}$ and unconstitutional overbreadth typically hinges on the statute's precise wording. Or so the judges claim. A review of the case law reveals the difficulty of construing Talley and of drawing principled distinctions between disclosure statutes that are overly broad and those that are narrowly tailored. ${ }^{37}$ This is not to say that the decisions are arbitrary. Rather, the cases illustrate that what controls is not the sweep of the statute, but the court's view of the statute's usefulness in informing voters and in enhancing the quality of public debate. ${ }^{38}$

Lower courts that have invalidated disclosure statutes typically have found the state's interest in regulating anonymous speech insufficient. ${ }^{39}$ These courts often rely on Justice Holmes's market conception of the First Amendment-that "the best test of

${ }^{35}$ For a discussion of free speech tradeoffs, see Richard A. Posner, Free Speech in an Economic Perspective, 20 Suffolk U L Rev 1 (1986).

${ }^{36}$ For an overview of the various state statutes, see Erika King, Comment, Anonymous Campaign Literature and the First Amendment, 21 NC Cent L J 144, 148 (1995) ("The only safe generalization to be made is that the majority of states require disclosure of the party financing the writing, and very few require disclosure of the author.") (emphasis in original).

${ }^{37}$ For example, courts have disagreed over whether a disclosure statute limited to statements concerning candidates for elective office qualifies as sufficiently narrowly tailored. Contrast United States v Insco, 365 F Supp 1308, 1312 (M D Fla 1973) (distinguishing federal disclosure statute from statute in Talley and upholding on grounds that federal statute only concerns candidates), with People $v$ Bongiorni, 205 Cal App 2d Supp 856, 23 Cal Rptr 565, 565-66 (1962) (holding state statute limited to statements concerning candidates insufficiently distinguishable from statute in Talley and therefore unconstitutional).

${ }^{38}$ Contrast State $v$ Petersilie, 334 NC 169, 432 SE2d 832, 843 (1993) (Source identification "is required in order for the electorate to determine what weight, if any, should be given [an] accusation, even if it is true."), with People $v$ White, 116 Ill 2d 171, 506 NE2d 1284,1288 (1987) ("In our opinion, the voters of this State are perfectly capable of assessing the merits of a viewpoint even though the person expressing it does not reveal his identity.").

${ }_{39}$ See, for example, White, 506 NE2d at 1287 (concluding that state's interest in preserving the integrity of the electoral process "does not... have any talismanic significance, and its bare invocation cannot serve to uphold the statute"); State v Fulton, 337 S2d 866, 871 (La 1976); State $v$ North Dakota Education Association, 262 NW2d 731, 736 (ND 1978) ("WW]e can sympathize and even agree with the motives of the sponsors [of the disclosure statute]. . . . But constitutional imperatives must prevail ...."). 
truth is the power of the thought to get itself accepted in the competition of the market ... . ${ }^{40}$ In this sense, the fact that a communication is anonymous is merely one of many factors to be considered when evaluating the statement's truth. Accordingly, voters are free to attach whatever significance they wish to anonymity. Some courts seize the opportunity to praise the sophistication of the electorate: "Voters are not sheep, and it is implausible to suppose that they will ignore the circumstance of anonymity in evaluating the message." ${ }^{11}$

These courts have not denied a state's interest in informing voters. Rather, they have suggested that this informational interest is not strong enough to justify restrictions on political speech. The Illinois Supreme Court, for example, downplayed the state's informational interest and invalidated the state's disclosure statute, noting that "[ $t]$ he State's fear that voters might make an illadvised choice does not provide the State with a compelling justification for limiting speech." ${ }^{.42}$ Alternatively, some courts do not deprecate the state's informational interest, but instead indicate that a disclosure statute is a poor means of furthering it. ${ }^{43} \mathrm{Un}$ der this view, the additional information such a statute provides is marginal at best. Finally, nearly every court that has invalidated a state disclosure statute has invoked Talley in emphasizing the benefits of anonymous political speech. ${ }^{44}$

In contrast, lower courts that have upheld state disclosure statutes in the face of First Amendment challenges generally

40 Abrams $v$ United States, 250 US 616, 630 (1919) (Holmes dissenting). For a good example of a court that employed the marketplace metaphor, see People $v$ Duryea, 76 Misc 2d 948, 351 NYS2d 978, 996 (NY Sup Ct 1974).

1 White, $506 \mathrm{NE2d}$ at 1288. See also McIntyre, $115 \mathrm{~S} \mathrm{Ct}$ at $1520 \mathrm{n} \mathrm{11}$, quoting Duryea, 351 NYS2d at 996:

Don't underestimate the common man. People are intelligent enough to evaluate the source of an anonymous writing. They can see it is anonymous. They know it is anonymous. They can evaluate its anonymity along with its message, as long as they are permitted, as they must be, to read that message. And then, once they have done so, it is for them to decide what is "responsible", what is valuable, and what is truth.

42 White, 506 NE2d at 1288, quoting Brown v Hartlage, 456 US 45, 60 (1982). Brown, however, did not concern a disclosure statute; it involved a candidate charged with violating a statute prohibiting vote-buying when he pledged not to accept his full salary if elected. Brown was not cited by the McIntyre Court, so its applicability to this context is questionable.

${ }^{43}$ See, for example, Duryea, 351 NYS2d at 996 (arguing that voters are capable of discounting for anonymity).

4 See, for example, Fulton, 337 S2d at 867. 
have employed one or more of four overlapping justifications. First, by discouraging reckless and inaccurate attacks, disclosure statutes promote the state's interest in ensuring that its elections are conducted honestly and fairly. ${ }^{45}$ Second, disclosure statutes play an important role in informing the electorate by enabling voters to weigh bias. ${ }^{46}$ This justification recognizes that the speaker's identity is itself an important component in the total mix of information confronting the listener-voter. Third, disclosure statutes help candidates refute charges by identifying the source of an attack. Presumably this qualifies as a state interest in that effective rebuttal-or the threat of rebuttal-enhances the overall quality of public debate. ${ }^{47}$ Finally, courts that have upheld disclosure statutes often have taken a dim view of anonymous communications in general. Consider the language of a Pennsylvania court affirming the constitutionality of a state statute prohibiting anonymous political publications: "[The statute] is an attempt to raise the ethical standards of political discussion, to promote fair play and fair competition in politics, to banish cowards from the political arena, and extirpate the dirty business of surreptitious character assassination." ${ }^{38}$

The approaches taken by pre-McIntyre courts generally reflect attempts to balance a state's informational interest, and its interest in regulating its elections, against speakers' First Amendment rights. Although the cases typically begin by examining the concrete statutory language at issue, the holdings are premised on more ethereal considerations-namely, the costs and benefits of requiring disclosure. Quantifying these costs and benefits is a tough task premised on hazy empirical judgments. Will forced disclosure chill valuable political speech? How helpful to a voter is a speaker's identity? And won't disclosure only chill relatively worthless speech, such as personal attacks on an oppo-

45 See, for example, KVUE, Inc. $v$ Moore, 709 F2d 922, 937 (5th Cir 1983) (observing that Texas disclosure statutes are "generally-applicable and evenhanded regulations that protect the integrity and reliability of the electoral process itself"), quoting Anderson $v$ Celebrezze, 460 US 780, 788 n 9 (1983); Morefield v Moore, 540 SW2d 873, 874 (Ky 1976) (upholding Kentucky statute designed "to promote honesty and fairness in the conduct of election campaigns").

${ }_{46}$ See, for example, State $v$ Acey, 633 SW2d 306, 307 (Tenn 1982) (Disclosure statutes "ensure that voters have information which will aid them in assessing the bias, interest, and credibility of the person or organization disseminating information about political candidates, and in determining the weight to be given a particular statement.").

47 See Canon v Justice Court, 61 Cal 2d 446, 39 Cal Rptr 228, 231 (1964) (in bank) (Enabling candidates to refute charges helps ensure that elections are the result of a well informed public will.).

4 Commonwealth $v$ Evans, 156 Pa Super 321, 40 A2d 137, 138-39 (1944). 
nent? The courts' answers to these questions are factored into the balance and determine whether a statute is unconstitutionally overbroad. What ostensibly begins as a close analysis of statutory language dissolves into a pragmatic inquiry, resulting in a predictably wide range of conclusions among the courts.

The pre-McIntyre courts' differing treatment of disclosure statutes resulted in part from the vast, uncharted middle ground between Talley and Buckley. Somewhere between the sweeping Los Angeles ordinance and the minimally restrictive federal statute lay the line between the constitutionally permissible and the constitutionally impermissible.

\section{MCINTYRE: A RECIPE FOR UNCERTAINTY}

McIntyre presented the Court with an opportunity to smooth out the inconsistencies resulting from the lower courts' hesitant attempts to reconcile Talley and Buckley. But although the Court spoke decisively in striking down Ohio's disclosure statute, it failed to articulate its reasoning clearly. ${ }^{49}$ As a result, the lower courts will continue to face uncertainty regarding the constitutionality of election-related restraints on speech. The dividing line between constitutional and unconstitutional remains hazy.

\section{A. McIntyre}

Margaret McIntyre was fined one hundred dollars for violating $\S 3599.09(\mathrm{~A})$ of the Ohio Elections Code by distributing anonymous handbills protesting a proposed school tax levy. ${ }^{50}$ She challenged the statute, which prohibited the distribution of political literature that omitted the name and address of the issuing individual or campaign official, ${ }^{51}$ on First Amendment grounds.

49 In his dissent, Justice Scalia rebuked the majority for the murkiness of its reasoning:

The Court's unprecedented protection for anonymous speech does not even have the virtue of establishing a clear (albeit erroneous) rule of law. ... It may take decades to work out the shape of this newly expanded right-to-speak-incognito, even in the elections field. And in other areas, of course, a whole new boutique of wonderful First Amendment litigation opens its doors.

Id at 1535 (Scalia dissenting).

${ }_{50}$ Some of the handbills she distributed identified her as the author. Others were attributed only to "CONCERNED PARENTS AND TAX PAYERS." The Ohio Elections Commission did not allege that her handbills were in any way libelous or misleading. McIntyre, $115 \mathrm{~S}$ Ct at 1514 \& $\mathrm{n} 2$.

s1 For the text of $\S 3599.09(\mathrm{~A})$, see note 5 . 
She claimed that the First Amendment protected anonymous speech, that Ohio's statute was not narrowly tailored, and that the statute did not serve a compelling state interest. ${ }^{52}$ The Ohio Supreme Court upheld the statute, finding it a "minor requirement" that "neither impacts the content of [the speakers'] message nor significantly burdens their ability to have it disseminated. ${ }^{953}$ Weighing the state interests in preventing fraud and informing the electorate against the burden placed upon speakers, the court found $\S 3599.09(\mathrm{~A})$ a reasonable and nondiscriminatory election law. ${ }^{54}$

The United States Supreme Court disagreed. In a majority opinion written by Justice Stevens, the Court found that the Ohio court had employed too lenient a standard of review. $.^{55} \mathrm{Al}-$ though laws that merely "control the mechanics of the election process" are properly reviewable under a relatively permissive balancing test, the same does not apply to laws that constitute a "regulation of pure speech." ${ }^{36}$ Thus, the Court held, "[w]hen a law burdens core political speech, we apply 'exacting scrutiny,' and we uphold the restriction only if it is narrowly tailored to serve an overriding state interest. ${ }^{157}$

${ }^{52}$ See Brief of Petitioner at 8-9.

33 McIntyre v Ohio Elections Commission, 67 Ohio St 3d 391, 618 NE2d 152, 155 (1993). The Ohio Supreme Court affirmed the decision of the Ohio Tenth District Court of Appeals. Only the trial court, the Franklin County Court of Common Pleas, found the statute unconstitutional. See id at 152.

st Id at 155-56.

ss McIntyre, $115 \mathrm{~S} \mathrm{Ct}$ at 1518-19. The Ohio court reviewed $\S 3599.09$ (A) under the standard established in Anderson $v$ Celebrezze, 460 US 780, 789 (1983). In that case, the Court reviewed another election regulation challenged on First Amendment grounds. John Anderson, an independent presidential candidate, alleged that Ohio's early filing deadline for presidential candidates placed an unconstitutional burden on his and his supporters' voting and associational rights. Id at 782 . The Court invalidated the regulation and established a balancing test for reviewing constitutional challenges to state election laws. Under this test, a court must first determine the character and magnitude of the injury to the plaintiff's First Amendment rights. The court must then weigh these considerations against the legitimacy and strength of the state's interests underlying the regulation. Id at 789.

ss McIntyre, $115 \mathrm{~S}$ Ct at 1518. The Court distinguished $\S 3599.09$ (A) from the statutory provisions challenged in Storer $v$ Brown, 415 US 724 (1974) (ballot qualifications for candidates), and Anderson, 460 US 780 (filing deadlines for presidential candidates).

${ }^{57}$ McIntyre, $115 \mathrm{~S} \mathrm{Ct}$ at 1519. One intriguing aspect of the Court's decision is its failure to challenge seriously the premise that Ohio's disclosure statute was a viewpointneutral restriction on speech, even though common sense suggests that challengers of popular incumbents might have a greater need for anonymity. In a footnote, the Court conceded that "[a]rguably, the disclosure requirement places a more significant burden on advocates of unpopular causes than on defenders of the status quo. For purposes of our analysis, however, we assume the statute evenhandedly burdens all speakers who have a legitimate interest in remaining anonymous." Id at 1518 \& n 8. But see Anderson, 460 US 
The Court found Ohio's two asserted interests-preventing fraud and informing the electorate-insufficient. Other sections of the Ohio Elections Code already prohibited fraudulent or libelous statements; ${ }^{58}$ the disclosure statute was therefore supplementary at best. Moreover, the disclosure statute did not target only those anonymous statements that were fraudulent or libelous, but swept all anonymous statements into its ambit. The Court similarly dismissed Ohio's informational interest. The need to provide voters with additional relevant information, the Court reasoned, does not justify requiring a writer to make statements he would otherwise omit-particularly where, as here, the name and address of the author are probably meaningless to the recipient. $^{59}$ Yet the Court's careful language and qualified reasoning-measuring the value of the writer's name to the document's recipient $t^{60}$-suggests that under different circumstances, perhaps involving a different class of writers or recipients, the Court might find a state's informational interest sufficient, and its disclosure statute constitutional.

The Court carefully wove its way through First Amendment and election law precedent, distinguishing both Talley and Buckley. Talley was easy: the ordinance at issue there prohibited anonymous handbilling in any place and under any circumstances, whereas Ohio's statute encompassed only those documents intended to influence the electoral process. ${ }^{61}$ In distinguishing Buckley, however, the Court relied on the nature of the regulated speech itself. Although the federal reporting statute upheld in

at 798 ("A State's claim that it is enhancing the ability of its citizenry to make wise decisions by restricting the flow of information to them must be viewed with some skepticism."). Indeed, a cynic would question this facial neutrality, finding it unsurprising that so many state legislatures-composed, after all, of incumbents-have sought to "raise the level of political debate" by outlawing a type of advertising often aimed at themselves.

${ }_{38}$ Sections 3599.091 and 3599.092 outlaw general campaign malfeasance, including false statements about one's opponent or oneself. Ohio Rev Code Ann §§ 3599.0913599.092 (Baldwin 1995).

s9 McIntyre, $115 \mathrm{~S}$ Ct at 1519-20:

Insofar as the interest in informing the electorate means nothing more than the provision of additional information that may either buttress or undermine the argument in a document, we think the identity of the speaker is no different from other components of the document's content that the author is free to include or exclude.

60 Id at 1520 .

61 Id at 1517. The Court noted that the Ohio and Los Angeles disclosure laws shared one infirmity: neither was limited to fraudulent or libelous statements. Id. 
Buckley required disclosure of campaign contributions and expenditures, that minor intrusion on First Amendment rights:

[I]s a far cry from compelled self-identification on all election-related writings. A written election-related document-particularly a leaflet-is often a personally crafted statement of a political viewpoint. ... As such, identification of the author against her will is particularly intrusive; it reveals unmistakably the content of her thoughts on a controversial issue. ${ }^{62}$

In distinguishing the two disclosure statutes, the Court thus recognized a higher level of protection for "personal" speech (as typified by a leaflet) than for "impersonal" speech (as typified by a campaign contribution) on the basis that the latter reveals far less about the speaker.

Finally, the Court echoed its language in Talley by highlighting the historical pedigree of anonymous speech. Permitting anonymous speech, the Court reasoned, not only benefits the individual by granting him protection from a hostile majority, but also enriches society by allowing unpopular ideas to enter the marketplace. Even if unwelcome initially, these ideas may gradually change public attitudes: "Under our Constitution, anonymous pamphleteering is not a pernicious, fraudulent practice, but an honorable tradition of advocacy and of dissent. ${ }^{p 3}$ In this sense, anonymity is simply the necessary price of a healthy and unmodified public debate.

Justice Scalia dissented, arguing that since the text of the Constitution was unclear on this question, "the widespread and long-accepted practices of the American people are the best indication of what fundamental beliefs it was intended to enshrine. ${ }^{64}$ He pointed out that every state except California has enacted some form of disclosure statute, the first doing so in $1890 .^{65}$ Furthermore, Scalia noted the dangers-and the "silli-

62 Id at 1523.

* Id at 1524. The Court cited, among others, James Madison, Alexander Hamilton, John Jay, Benjamin Franklin, Samuel Langhorne Clemens (Mark Twain) and William Sydney Porter (O. Henry) as famous authors who wrote under pseudonyms. Id at 1516-17, nn 4, 6 .

\& Id at 1534 (Scalia dissenting). In a concurrence, Justice Thomas concluded that the phrase "freedom of speech, or of the press," as originally understood, did in fact protect anonymous political leafletting. Id at 1525 (Thomas concurring).

${ }_{65}$ Id at 1533 (Scalia dissenting). See also id at 1530 ("At a time when both political branches of Government and both political parties reflect a popular desire to leave more decisionmaking authority to the States, today's decision moves in the opposite direction, 
ness" - that result from a generalized right to anonymous speech. For example, he questioned whether a public-access cable channel could refuse to permit anonymous, masked performances, or whether a government periodical must abandon its policy of prohibiting anonymous letters to the editor. ${ }^{66}$ But protecting anonymous communication risks more than silliness. Establishing a broad right to anonymity would eliminate one of the last remaining guarantors of civilized public debate. For those not constrained by their own conscience, public accountability serves as an excellent deterrent of outrageous or patently offensive speech-particularly during an election. As Justice Scalia concluded, recognizing all anonymous communication as "traditionally sacrosanct [ ] seems ... a distortion of the past that will lead to a coarsening of the future. ${ }^{367}$

Two courts have applied McIntyre to disclosure statutes. But neither case sheds much light on the likely course of postMcIntyre jurisprudence. In FEC v Survival Education Fund, Inc., the Second Circuit upheld a federal law that requires individuals who finance direct mailings to raise money for political campaigns to disclose their identities within the mailing. ${ }^{68}$ This decision is unhelpful because the court confined its analysis to state regulation of political fund raising, explicitly avoiding the thornier question of political advertising. ${ }^{69}$ And in State $v$ Moses, a Louisiana court deemed McIntyre "sufficient authority" to strike down a broad state statute that prohibited any person or organization from anonymously disseminating any sort of communication that related to candidates or ballot propositions. ${ }^{70}$ This case is similarly unhelpful: the court conceded that its own precedent alone made for an easy decision. ${ }^{71}$ Although Survival Education Fund suggests that McIntyre will not be extended to protect so-

adding to the legacy of inflexible central mandates (irrevocable even by Congress) imposed by this Court's constitutional jurisprudence.").

${ }^{66}$ Id at 1535.

67 Id at 1537.

${ }^{68} 65$ F3d 285, 295-98 (2d Cir 1995). The challenged statute was the Federal Election Campaign Act, 2 USC § 441d(a).

69 See Survival Education Fund, 65 F3d at 296 ("Whatever the effect of McIntyre on the constitutionality of [ ] political advertising (an issue we do not address), the issue before us is solely whether requiring a disclosure by a group that is soliciting a contribution runs afoul of the First Amendment.").

${ }_{70} 655$ S2d 779, 781-82 (La Ct App 1995).

${ }^{71}$ See id ("In view of our own jurisprudence and state constitution, the state interest required to justify even a limited prohibition on election-related anonymous literature in Louisiana should be much more compelling than that which theoretically the U.S. Supreme Court might have found sufficient . . . "). 
licitation speech by fund raisers, this result is unsurprising given McIntyre's reaffirmation of Buckley and the importance of identifying campaign contributors. The shape of post-McIntyre jurisprudence remains uncertain.

\section{B. Critique of McIntyre}

The majority's opinion left several puzzles for lower courts seeking to determine the sweep of the holding. Three points in particular warrant emphasis. First, it is unclear precisely when a law burdens "core political speech" and when it merely "controls the mechanics of the electoral process." The distinction is crucial: laws that burden core political speech trigger the formidable "exacting scrutiny" test and must be narrowly tailored to serve an overriding state interest. ${ }^{72}$ By comparison, laws that regulate elections remain reviewable under a balancing test.

Clearly, many provisions of state election codes both regulate the electoral process and burden speech. ${ }^{73}$ It will likely fall to the lower courts to draw meaningful distinctions among contested regulations in determining the proper standard of review. Although McIntyre offers little guidance as to how to classify election laws, the Court nevertheless indicated that core political speech encompasses a vast range of speech, including discussion of governmental affairs, debate over candidates' qualifications, and speech concerning public issues in general. ${ }^{74}$ The Court's broad language suggests that in borderline cases, a disclosure statute will be reviewed with exacting scrutiny.

Second, even if speech constitutes "core political speech," under what circumstances may it be subject to state regulation? The obvious answer is that it may be regulated to secure a sufficiently compelling state interest, provided that the statute is narrowly tailored. But this just begs the question: after McIntyre, is there any state interest strong enough to withstand the withering gaze of exacting scrutiny? The Court's answer borders on

72 Justice Scalia referred to this imposing hurdle as "ordinarily the kiss of death." See McIntyre, 115 S Ct at 1535 (Scalia dissenting).

${ }_{73}$ For example, many states prohibit judicial candidates from discussing how they would rule in future cases. See Berger $v$ Supreme Court of Ohio, 598 F Supp 69, 75-76 (S D Ohio 1984), aff'd without opinion, 861 F2d 719 (6th Cir 1988) (upholding state restrictions on judicial candidate speech).

${ }^{34}$ McIntyre, $115 \mathrm{~S} \mathrm{Ct}$ at 1518-19 ("Discussion of public issues and debate on the qualifications of candidates are integral to the operation of the system of government established by our Constitution. The First Amendment affords the broadest protection to such political expression. ... ."), quoting Buckley, 424 US at 14. 
the cryptic. After condemning the overbreadth of the Ohio statute, the Court conceded that "a State's enforcement interest might justify a more limited identification requirement ...." Yet the Court failed to elaborate on what might constitute a sufficient enforcement interest, ${ }^{76}$ or, for that matter, a sufficiently limited identification requirement.

In a concurring opinion, Justice Ginsburg sought to limit the scope of the majority's decision. Agreeing that the Ohio statute was unconstitutional as applied to Mrs. McIntyre, Ginsburg cautioned: "We do not thereby hold that the State may not in other, larger circumstances, require the speaker to disclose its interest by disclosing its identity." W77 What precisely constitutes these "other, larger circumstances" remains to be answered by future courts.

Third, the decision leaves open the degree of First Amendment protection afforded core political speech in other media, such as broadcast television and radio. The actual holding is narrowly confined to written communication, and the Court explicitly declined to review the constitutionality of $\S 3599.09$ (B) of the Ohio Elections Code, which prohibits anonymous speech uttered over the broadcasting facilities of any Ohio radio or television station, since the provision was not at issue in the case. ${ }^{78}$ Moreover, the Court implied that a state might indeed have a stronger interest in requiring disclosure for statements broadcast to the public, as opposed to statements distributed in written form. ${ }^{79}$

75 McIntyre, $115 \mathrm{~S}$ Ct at 1522.

${ }^{76}$ Preventing fraud or libel would presumably not be sufficient when the state's interests are already secured by other provisions of the election code. See note 58 and accompanying text.

${ }_{77}$ Id at 1524 (Ginsburg concurring). Justice Ginsburg praised the Court for "[a]ppropriately leaving open matters not presented by McIntyre's handbills . . . ." Id.

${ }_{78}$ McIntyre, $115 \mathrm{~S} \mathrm{Ct}$ at 1514-15 n 3. The provision in question provides:

No person shall utter or cause to be uttered, over the broadcasting facilities of any radio or television station within this state, any communication which is designed to promote the nomination or election or defeat of a candidate, or the adoption or defeat of any issue or to influence the voters in any election, unless the speaker identifies himself with his name and residence address or unless such communication identifies the chairman, treasurer, or secretary of the organization responsible for the same with the name and residence or business address of such officer....

Ohio Rev Code Ann § 3599.09(B) (Baldwin 1995). The statute permits radio stations not to broadcast the residence or business address of the officer, as long as it keeps the address on file and divulges it to any person upon request. Id.

${ }^{79}$ See McIntyre, $115 \mathrm{~S} \mathrm{Ct}$ at 1516 ("Whatever the motivation may be, at least in the field of literary endeavor, the interest in having anonymous works enter the marketplace 
But to the extent that the value of anonymous speech lies in its potential to change majority attitudes, limiting its form to printed material-and denying it the vast audience reached by modern broadcast technology-appears a hollow protection at best. In short, it is difficult to gauge from McIntyre the importance of allowing anonymous statements to enter the marketplace when the context shifts from a print to a broadcast medium. The urgent emphasis on the social benefits of anonymous speech seems universally applicable to all media, yet the Court's carefully qualified language undercuts any firm conclusions.

\section{Reviewing State Disclosure Statutes}

A broad reading of McIntyre threatens to cut a wide swath through state election codes. Such a reading should be rejected. Indeed, the Court openly acknowledged that states may still regulate political speech, circumscribing the scope of its opinion by recognizing that "Buckley may permit a more narrowly drawn statute" and by condemning Ohio's "blunderbuss approach." This Section interprets McIntyre in the context of the Court's prior jurisprudence, arguing that courts should uphold disclosure statutes provided that the statutes are limited to (a) broadcast communication and (b) speech by candidates for elective office. Not only does this type of speech implicate stronger state interests, but the speaker has a weaker claim to First Amendment protection.

Under the framework offered here, four types of political communication exist: (1) print speech by private individuals; (2) broadcast speech by private individuals; (3) print speech by candidates; and (4) broadcast speech by candidates. Anonymous speakers in the first category are clearly protected under McIntyre; this Section concludes that McIntyre should not extend to the fourth. Categories two and three, although not directly controlled by McIntyre, will likely fall within its sweep. The Court's recognition of the "honorable tradition" of anonymous leafletting (suggesting protection of anonymous print speech by candidates), coupled with its hesitation to force disclosure by "Ione protestors" (suggesting protection of anonymous broadcast speech by private individuals), indicates McIntyre's applicability 
to categories two and three. Nonetheless, such a prediction is inevitably speculative and, as noted above, is hampered by the many ambiguities in the Court's opinion. ${ }^{81}$

As for category four, there are very sound policy reasons for prohibiting anonymous broadcast speech by candidates. ${ }^{82}$ But disclosure statutes must now be reviewed within the framework established by the Court, and policy must yield to the First Amendment. This Comment seeks to halt the application of McIntyre through constitutional argument, working within the Court's framework, by drawing a line between categories three and four.

\section{A. Broadcast Speech: Diluted First Amendment Protections}

\section{A history of stricter regulation.}

A disclosure statute is more likely to survive First Amendment review if it is confined to broadcast communication. Historically, the Court has applied lighter First Amendment scrutiny to restrictions on broadcast communication than to restrictions on print communication. ${ }^{83}$ Consider in this light the Court's past treatment of restrictions on election-related speech in each medium. The Court has upheld an FCC regulation requiring broadcasting stations to allow candidates for federal office reasonable access on behalf of their candidacy. ${ }^{84}$ The Court's willingness to infringe upon election-related speech in a broadcast context contrasts with its reluctance to uphold similar restrictions on election-related print communication. For example, the Court has held that a state cannot require a newspaper to provide a political candidate space to reply to criticism previously published in an editorial. ${ }^{85}$

${ }^{81}$ See Section II.B.

82 See text accompanying notes 98-107. Again, the prediction that McIntyre will likely apply to categories two and three is not to say that invalidating those types of disclosure statutes is necessarily a wise idea.

${ }^{83}$ See Cass R. Sunstein, Democracy and the Problem of Free Speech 108 (Free Press 1993) ("Under current law, government has little power to regulate the print media, whereas the Court allows a range of restrictions on broadcasters."), citing FCC $v$ Pacifica Foundation, 438 US 726 (1978), Red Lion Broadcasting Co. v FCC, 395 US 367 (1969), and National Broadcasting Co. $v$ United States, 319 US 190 (1943).

84 CBS, Inc. $v$ FCC, 453 US $367,396-97$ (1981). For a discussion of regulating televised election-related speech, see generally Timothy J. Moran, Format Restrictions on Televised Political Advertising: Elevating Political Debate Without Suppressing Free Speech, 67 Ind I J 663 (1992).

Bs Miami Herald Publishing Co. v Tornillo, 418 US 241, 244, 256-58 (1974). See also id at 259 (White concurring) (" $\mathrm{A}$ newspaper or magazine is not a public utility subject to 
Commentators and the Court itself have advanced several theories for this differing treatment. The most common explanation is scarcity: since there are more would-be broadcasters than available frequencies, government must allocate licenses, and therefore has a freer hand in regulating the resulting communication. ${ }^{86}$ Another explanation rests on a "social impact" theory-that broadcast is inherently a more intrusive medium than print (since children or unsuspecting adults may inadvertently view offensive material broadcast into their homes) ${ }^{87}$ To be sure, the scarcity rationale is evaporating in light of the expansion of cable television, and disclosure statutes are not aimed at regulating obscene material. But the Court's precedent clearly indicates that government stands on far firmer constitutional ground when regulating broadcast speech. As the Court recently observed, "[i]t is true that our cases have permitted more intrusive regulation of broadcast speakers than of speakers in other media." ${ }^{88}$

\section{Disclosure statutes as a means of self-governance.}

In permitting more intrusive regulation of broadcast communication, the Court has invoked a theory of the First Amendment as a means of self-governance. This conception of freedom of speech as applied to broadcasting was first articulated by the Court in Red Lion Broadcasting Co. v FCC, where the Court recognized citizens' "collective right to have the [broadcast] medi-

'reasonable' governmental regulation in matters affecting the exercise of journalistic judgment as to what shall be printed.").

${ }_{86}$ See, for example, Turner Broadcasting System, Inc. v FCC, 114 S Ct 2445, 2457 (1994) ("Although courts and commentators have criticized the scarcity rationale since its inception, we have declined to question its continuing validity as support for our broadcast jurisprudence, and see no reason to do so here.") (footnotes and citations omitted); FCC v League of Women Voters, 468 US 364, 377 (1984) ("The fundamental distinguishing characteristic of the new medium of broadcasting . . . is that ' $[\mathrm{b}]$ roadcast frequencies are a scarce resource [that] must be portioned out among applicants." ), quoting Columbia Broadcasting Sys., Inc. v Democratic Natl Comm., 412 US 94, 101 (1973).

87 See, for example, Pacifica, 438 US at 748 (Broadcasting has a "uniquely pervasive presence in the lives of all Americans."). In addition to the scarcity and social impact rationales, a variety of other theories have been advanced to explain the differing treatments. For a general discussion of these theories, see Sunstein, Democracy and the Problem of Free Speech at 108-14 (cited in note 83).

88 Turner, $114 \mathrm{~S} \mathrm{Ct}$ at 2456. See also Pacifica, $438 \mathrm{US}$ at 748 ("[O]f all forms of communication, it is broadcasting that has received the most limited First Amendment protection."); Red Lion, 395 US at 388 ("Where there are substantially more individuals who want to broadcast than there are frequencies to allocate, it is idle to posit an unabridgeable First Amendment right to broadcast comparable to the right of every individual to speak, write, or publish."). 
um function consistently with the ends and purposes of the First Amendment. It is the right of the viewers and listeners, not the right of the broadcasters, which is paramount. ${ }^{n 89}$ In this view, the purpose of the First Amendment is to enrich public debate and promote informed democratic deliberation..$^{90}$ Often the selfgovernance conception collides with the First Amendment's goal of protecting self-expression. As one commentator summarized the conflict:

[F]irst amendment protection of speech has a dual function: it serves not only to ensure that each individual is free to speak out, but also to enhance the likelihood that the public can hear all facets of everything that is pertinent to the decisions it must make. The public's first amendment rights as hearers are just as important as their rights as speakers. ${ }^{91}$

The distinction between citizens' rights as speakers and their rights as listeners is helpful in considering the purpose of disclosure statutes. A disclosure statute is essentially a "precommitment strategy" - a means by which citizens, acting through their state legislatures, can determine in advance the process for choosing their elected officials. In this sense, a disclosure statute represents the electorate's considered finding that it does not want to be influenced by anonymous advertisements in reaching a voting decision. Empirical research suggests that this may be a wise choice: studies have shown that if a television advertisement can be made to seem neutral or authoritative, viewers will later think they got the information from watching the news. ${ }^{93}$ Disclo-

в9 395 US 367, 389-90, 396 (1969) (upholding fairness doctrine mandating air time for opposing views).

so See Alexander Meiklejohn, The First Amendment is an Absolute, $1961 \mathrm{~S} \mathrm{Ct} \mathrm{Rev}$ 245, 252-57 (outlining the self-governance theory of the First Amendment).

91 Joel L. Fleishman, Freedom of Speech and Equality of Political Opportunity: The Constitutionality of the Federal Election Campaign Act of 1971, 51 NC L Rev 389, 427 (1973).

${ }^{92}$ Sunstein describes precommitment strategies as a way for citizens to "overcome their own short-sightedness or absence of deliberation." See Sunstein, Democracy and the Problem of Free Speech at 74-75 (cited in note 83). Another example of a precommitment strategy is the constitutional provision limiting presidents to two terms in office. Id at 74 . Sunstein also classifies the Constitution itself as a precommitment strategy since it "persistently foreclos[es] choices in individual cases." See id at 75.

${ }^{93}$ See Thomas B. Rosenstiel, FCC Rule Calls for Election Ads to Name Source, LA Times A7, A7 (Jan 2, 1992). See also Kathleen Hall Jamieson, Dirty Politics: Deception, Distraction, and Democracy 230-34 (Oxford 1992) (discussing the different forms these advertisements take); Michael Pfau and Henry C. Kenski, Attack Politics: Strategy and Defense xiii (Praeger 1990) (citing studies documenting the effectiveness of "attack ads"). 
sure statutes limit self-expression, but facilitate self-governance by requiring a basic and meaningful piece of information-the speaker's identity - as the price of entry into the marketplace of campaign speech. The Court's communications jurisprudence, in Red Lion and elsewhere, illustrates that the purpose of disclosure statutes dovetails with the Court's conception of the First Amendment in a broadcast medium.

Restricting political speech to further self-governance is often controversial: a common counterargument is that the restrictions muzzle self-expression. ${ }^{94}$ By prohibiting anonymous speech, disclosure statutes are guilty as charged. But the counterargument seems less persuasive when applied to candidates who broadcast campaign commercials. This is because during an election, the interest in self-governance is arguably at its peak. As the Court observed in Burdick $v$ Takushi, a case in which it upheld a state's prohibition of write-in voting, "[a]ttributing to elections a more generalized expressive function would undermine the ability of states to operate elections fairly and efficiently." ${ }^{95}$ Permitting a candidate to broadcast anonymous speech risks precisely this. Particularly in the context of an election, self-governance should not be sacrificed to candidate self-expression.

Finally, disclosure statutes confined to broadcast communication reduce the risk of selective enforcement. The Court has long recognized the danger of government officials singling out antigovernment speech. ${ }^{96}$ Speech criticizing incumbent officials typically reaches its peak during election seasons, when thousands upon thousands of political messages-including campaign brochures, fliers, and broadcast advertisements-reach the public. Clearly, not all of this material can be monitored for conformity to disclosure laws, nor (given limited state resources) can every violation be prosecuted. Accordingly, when partisan political officials serving on state election boards are tasked with monitoring partisan political advertisements, there arises a very real risk of selective enforcement. Vindictive and opportunistic politicians may pressure the election board into punishing their oppo-

24 See, for example, Seth F. Kreimer, Sunlight, Secrets, and Scarlet Letters: The Tension Between Privacy and Disclosure in Constitutional Law, $140 \mathrm{U}$ Pa L Rev 1, 26-54 (1991) (discussing chilling effects of government-mandated disclosure).

${ }_{95} 504$ US 428, 438 (1992). See also Garrison v Louisiana, 379 US 64, 74-75 (1964) ("S]peech concerning public affairs is more than self-expression; it is the essence of selfgovernment.").

${ }_{96}$ See note 18 and accompanying text. 
nents-one need look no further than the facts of McIntyre to recognize this risk. ${ }^{97}$

Confining disclosure statutes to broadcast communication reduces this risk for two main reasons. First, there are simply far fewer candidate commercials on television and radio than there are fliers and leaflets distributed on street corners or mailed to voters. Second, the distribution points of broadcast communications are centralized: in any state, there exist but a limited number of television and radio stations that air political commercials. In short, it is far easier to monitor the activities of a limited number of broadcast stations than to police every street corner and shopping mall in America. Limiting the regulatory field increases the visibility of any particular regulatory act or omission. The risk of selective enforcement does not evaporate, but clearly diminishes, when disclosure statutes are limited to broadcast communications.

Under the McIntyre framework, any restriction on core political speech must be reviewed with exacting scrutiny. So although a disclosure statute limited to broadcast communication is more constitutionally permissible than one that encompasses print, the statute still needs to rest on something more substantial than a history of regulation. That is the concern of the next Section.

\section{B. Candidate Speech Is Distinguishable from Other Political Speech}

The overly broad Ohio statute invalidated in McIntyre regulated political speech by all citizens. One way to narrow a disclosure statute is to restrict only the speech of candidates for elective office. ${ }^{98}$ Such a statute leaves untouched anonymous speech by private individuals like Mrs. McIntyre, without clearing the way for candidates to engage in anonymous warfare over the airwaves. More importantly, statutes confined to candidate speech are not only backed by a stronger state informational

97 A local school district official, who supported the tax proposal, reported Mrs. McIntyre to the Ohio Elections Commission, which imposed the one-hundred-dollar fine. McIntyre, 115 S Ct at 1514.

${ }_{98}$ Candidate speech includes speech not only by the candidate himself and campaign staffers, but also by state political parties and other groups, such as political action committees, that act with the campaign's guidance. For a discussion of regulations of speech by groups that support a candidate but act independently of the campaign, see generally Mitchell L. Gaynor, Note, Curbing Injurious PAC Support Through 2 U.S.C. \& 441d, 35 Hastings L J 869 (1984). 
interest, but also constitute a less severe imposition on the speaker's First Amendment rights.

1. State informational interests are stronger.

Disclosure statutes that require candidates to identify themselves as the source of a political advertisement serve stronger state informational interests than the Ohio statute struck down in McIntyre. The Court rejected Ohio's claim that the name of an unknown protester on a leaflet would materially enhance a voter's ability to evaluate the message therein. ${ }^{99}$ This is eminently plausible: the name of a private citizen shrouded in obscurity serves little, if any, informational interest. But where the speaker is a candidate, his name is far more recognizable to the general public. Accordingly, the voter's ability to discount for bias and general credibility is materially enhanced by learning the source. This increased informational interest-furthering a voter's evaluation of the speaker's message-represents a fundamental difference between a state's interest in a disclosure statute limited to candidates and the (insufficient) interest alleged by Ohio.

Candidate disclosure fulfills another informational interest: it facilitates evaluation of the speaker himself. This interest is virtually meaningless where the speaker is a private citizen. But if a candidate is speaking, the state's interest in facilitating public evaluation of the speaker assumes heightened importance. ${ }^{100}$ Consider the difference between political speech by a candidate urging a vote against his opponent and political speech by a private citizen urging a vote against a ballot initiative. Both speakers are, in a sense, "biased," and their identities are often important components of evaluating their respective messages. But only when the candidate is speaking does the listener have an interest in evaluating the speaker. Whereas a ballot question, or a debate over a pending bill, is a choice among incorporeal public policies, a candidate election is a different animal entirely: it is a choice between specific individuals, or more precisely, between

99 " $[\mathrm{I}] \mathrm{n}$ the case of a handbill written by a private citizen who is not known to the recipient, the name and address of the author adds little, if anything, to the reader's ability to evaluate the document's message." McIntyre, $115 \mathrm{~S} \mathrm{Ct}$ at 1520.

100 The Court has recognized that enhancing the public's knowledge about candidates for elective office is a valid public interest. See Anderson v Celebrezze, 460 US 780, 796 (1983) ("There can be no question about the legitimacy of the State's interest in fostering informed and educated expressions of the popular will in a general election."). 
speakers. ${ }^{101}$ In this sense, "[t]he source of the charge is as much at issue as the charge itself"; ${ }^{102}$ candidates are vetted in part on how they conduct their campaigns for office. Indeed, the very fact that candidates frequently strike their names from negative advertisements $^{103}$ strongly supports the conclusion that a candidate's name is meaningful to the electorate. Requiring disclosure only when the speaker himself is a candidate thus serves greater state informational interests than requiring disclosure for all speakers.

In reviewing disclosure statutes, courts should accordingly distinguish between the general class of political speech and the narrow class of candidate speech. This approach is reflected in several pre-McIntyre decisions by state courts sustaining disclosure statutes regulating speech by or about political candidates. These courts generally have emphasized that the significance of the speaker's identity takes on added informational meaning during an election. ${ }^{104}$ Election-related speech restraints have often been upheld as a means of preventing fraud or the corruption of the political process. ${ }^{105}$ But in the wake of McIntyre's rejection of Ohio's interest in stemming fraud as a justification for a disclosure statute (at least when that interest is already ad-

${ }^{101}$ The Court has recognized, in other contexts, the difference between political speech involving candidates and political speech involving ballot questions. For example, the Court has acknowledged that greater regulation of speech is necessary to prevent fraud and libel in a candidate election than in a ballot question. Citizens Against Rent Control $v$ City of Berkeley, 454 US 290, 296-99 (1981).

102 State $v$ Petersilie, 334 NC 169, 432 SE2d 832, 843 (1993).

${ }^{103}$ See text accompanying note 116.

${ }_{104}$ In each case, the court recognized that disclosure statutes served a greater state informational interest in an election context. See, for example, State $v$ Acey, 633 SW2d 306, 307 (Tenn 1982) (Disclosure statutes "ensure that voters have information which will aid them in assessing the bias, interest, and credibility of the person or organization disseminating the information about political candidates, and determining the weight to be given a particular statement."); Petersilie, 432 SE2d at 842 ("In the context of a campaign it is necessary for accusers of candidates to identify themselves, even if they speak the truth, in order for the electorate to be able to assess the accusers' bias and interest."); Canon v Justice Court, 61 Cal 2d 446, 39 Cal Rptr 228, 235 (1964):

[A]nonymity all too often lends itself, in the context of attacks upon candidates in the pre-election period, to smears, as a result of which the electorate is deceived. Identification permits confrontation and often makes refutation easier and more effective. It tends to reduce irresponsibility. It enables the public to appraise the source.

${ }^{105}$ First National Bank of Boston v Bellotti, 435 US 765, 788-89 (1978) ("Preserving the integrity of the electoral process [and] preventing corruption .... are interests of the highest importance."). 
dressed by other provisions of the state election code ${ }^{106}$ ), courts will likely look to the informational interests served by such statutes. Statutes confined to candidate speech are, like the statute upheld in Buckley, "narrowly limited to those situations where the information sought has a substantial connection with the governmental interests sought to be advanced."107

\section{The speaker's interests are diminished.}

A disclosure statute limited to candidates for public office imposes a lesser burden on speakers' First Amendment rights than statutes not so limited. This is so for several reasons, all of which stem from the speaker's voluntary declaration of candidacy and pursuit of public office. First, a political candidate's need for anonymity is far weaker than that of a private citizen. Anonymity has traditionally been a refuge for speakers who fear retaliation for voicing unpopular views. The McIntyre Court's concern for a speaker's privacy interests echoed earlier decisions, such as NAACP $v$ Patterson, in which the Court struck down a disclosure statute based on the dangers of "economic reprisal, loss of employment, threat of physical coercion, and other manifestations of public hostility."108 Yet this reasoning weakens considerably when applied to candidates for public office. A candidate-and particularly a candidate hoping to communicate to thousands via his commercials-voluntarily presents himself to the electorate for its evaluation and approval. Courts should treat the very declaration of candidacy as representing a waiver of any constitutional privacy interests that would otherwise protect his public communications.

The Court's treatment of libel law is instructive in this context. What constitutes libel depends on whether the "victim" qualifies as a public figure: by becoming a public figure, one relinquishes a certain degree of protection from critical public statements. ${ }^{109}$ Even an unknown political candidate qualifies as a public figure. ${ }^{110}$ In the libel cases, the Court has recognized

108 NAACP v Patterson, 357 US 449, 462 (1958).

${ }_{109}$ See New York Times Co. $v$ Sullivan, 376 US 254, 279-83 (1964) (Restricting public officials' ability to recover for libel furthers larger First Amendment goals of ensuring robust public debate.); Curtis Publishing Co. v Butts, 388 US 130, 164 (1967) (Warren concurring) (New York Times standard applies to public figures as well as public officials.).

${ }^{110}$ See Monitor Patriot Co. $v$ Roy, 401 US 265, 271 (1971) ("[P]ublications concerning candidates must be accorded at least as much protection [from libel suits] under the First 
that minor restrictions on a public figure's legal protections can promote larger First Amendment goals by preserving a vigorous and free-flowing debate on issues of public concern. Applied to the context of a political campaign, a slight curtailment of a candidate's freedom to communicate anonymously-triggered by his voluntary quest for public office-similarly furthers the important First Amendment goal of an informed public debate over his candidacy.

Second, requiring source identification in commercials broadcast to further one's political campaign imposes no additional burden on the speaker's First Amendment rights. Consider in this light the reasoning of McIntyre: disclosure of authorship is "intrusive" because "it reveals unmistakably the content of [the author's] thoughts on a controversial issue."111 Again, this reasoning rings hollow in a campaign context. The entire purpose of a campaign is to build support by revealing-indeed, by disseminating as widely as possible - the contents of one's thoughts on controversial issues. It is hardly "intrusive" to require a candidate to disclose his thoughts on public affairs. It is even less intrusive to require a candidate to disclose authorship on his own commercials, which contain only those thoughts that he wishes to broadcast to the electorate.

Third, the nature of candidate speech differs dramatically from the speech protected by McIntyre. The Court distinguished Buckley by stressing the difference between an impersonal campaign contribution and a leaflet that is "often a personally crafted statement of a political viewpoint."112 A campaign commercial is hardly "personally crafted." Indeed, the contrary is true: political commercials are typically crafted by committee, often with little

and Fourteenth Amendments as those concerning occupants of public office."). See also Gertz $v$ Robert Welch, Inc., 418 US 323, 342 (1974) ("Those who, by reason of the notoriety of their achievements or the vigor and success with which they seek the public's attention, are properly clasisified as public figures ....") (emphasis added).

${ }^{111}$ McIntyre, $115 \mathrm{~S} \mathrm{Ct}$ at 1523. See also Brown v Socialist Workers '74 Campaign Committee, 459 US 87, 111-12 (1982) (O'Connor concurring in part and dissenting in part) ("Once an individual has openly shown his close ties to the organization by campaigning for it, disclosure of receipt of expenditures is unlikely to increase the degree of harassment so significantly as to deter the individual from campaigning for the party.").

${ }^{112}$ McIntyre, $115 \mathrm{~S} \mathrm{Ct}$ at 1523. Justice Ginsburg in particular focused on the fact that Mrs. McIntyre acted alone, likening the case to others involving solo protesters. McIntyre, $115 \mathrm{~S}$ Ct at $1524 \mathrm{nn} 1-2$ (Ginsburg concurring), citing City of Ladue v Gilleo, $114 \mathrm{~S} \mathrm{Ct}$ 2038, 2046-47 (1994) (homeowner displaying small antiwar sign on her own property), and United States v Grace, 461 US 171, 183 (1983) (lone picketer on public sidewalk outside Supreme Court building). 
input from the candidate himself. ${ }^{113}$ Many spots are aired only after extensive test marketing with focus groups-the very antithesis of personal crafting. ${ }^{114}$ Moreover, a candidate's speech as expressed in a commercial is inherently less "personal," since he is offering his policy positions expressly to secure public approval. A candidate's privacy interest (at least concerning his public remarks) is diluted if not entirely absent. Both in content and in origin, campaign speech thus differs from speech by a private individual. Candidate speech, like a campaign contribution, is intended purely to advance the campaign. In this sense, candidate commercials bear a closer relationship to the speech regulated in Buckley than the speech in McIntyre. Characterizing a modern campaign commercial as a personally crafted statement would rob the Court's careful distinction of Buckley of its meaning.

Fourth, and finally, candidates seeking to broadcast anonymous commercials can only hope for a mushy sort of anonymity at best. This is because expenditure disclosure laws require candidates to report all campaign funds spent on advertising. ${ }^{115}$ Given this information, the press, not to mention the candidate's opponents, will likely trace the advertisement to its source (assuming it is not readily apparent in the first place).

But even if candidates have little hope or expectation of preserving anonymity, they may have another hope: severing identification at the time of communication. When delivering a particularly harsh or personal attack, candidates consistently distance themselves from their messages. Consider the advice of two political consultants:

Keep your candidate out of the piece. ... By putting your candidate in the piece, you may risk associating him or her with the kind of message that you intend for your opponent. Moreover, it's always best to have someone else deliver the

113 See Ansolabehere and Iyengar, Going Negative 1, 146, 153-54 (cited in note 1).

114 See, for example, Elizabeth Kolbert, Test-Marketing a President, NY Times Magazine 18, 20 (Aug 30, 1992) (discussing candidates' reliance on focus groups in creating television commercials). For a general discussion of commercial techniques in political advertising, see Moran, 67 Ind $L J$ at 666-72 (cited in note 84).

"11 See Buckley, 424 US at 60-68 (upholding expenditure disclosure requirements for federal candidates). Justice Scalia's dissent in McIntyre noted the likely futility of anonymity: "Surely in many if not most cases, [expenditure reporting requirements] will readily permit identification of the particular message that the would-be-anonymous campaigner sponsored." McIntyre, $115 \mathrm{~S}$ Ct at 1537 (Scalia dissenting). 
negative message, even if it's a third-person, unsigned piece. Keep your candidate at a dignified distance. ${ }^{116}$

This suggests that candidates who communicate anonymously are not motivated by the desire to preserve their personal safety, but instead by the desire to preserve their popularity with the electorate. Candidates represent a class of individuals with a common motivation for desiring anonymity-a motivation inconsistent with the Court's recognized justifications for anonymous communication. Drawing a distinction between candidate speech and other political speech offers a workable bright-line rule for excluding a defined class of speakers from the protection of McIntyre.

\section{No chilling effect on speech.}

Disclosure statutes are vulnerable to charges that they produce a chilling effect on speech. This concern was echoed by the McIntyre Court, which worried that speakers who could not enter the marketplace anonymously would not enter the marketplace at all. ${ }^{117} \mathrm{~A}$ disclosure statute limited to candidate speech is unlikely to produce this kind of chilling effect. Under this Comment's proposal, anonymous speech can still enter the marketplace; it just cannot be voiced by candidates for office. Private individuals can continue to communicate to the public behind a veil of anonymity. Candidates can continue to exercise their full constitutional rights to speak or broadcast political messages as long as they acknowledge authorship. And to the extent that any candidate speech is chilled, it is likely to be only the most outrageous or offensive attacks-those for which the speaking candidate hopes to dodge accountability. In short, a statute requiring source identification in campaign commercials, if it alters the existing incentives at all, will likely improve the tenor of political debate rather than reduce the total amount of speech about public affairs.

116 Richard Schlackman and Jamie "Buster" Douglas, Attack Mail: The Silent Killer, Campaigns \& Elections 25, 67 (July 1995).

117 "[P]ersecuted groups and sects from time to time throughout history have been able to criticize oppressive practices and laws either anonymously or not at all." McIntyre, $115 \mathrm{~S} \mathrm{Ct}$ at 1516, quoting Talley, $362 \mathrm{US}$ at 64. 


\section{CONCLUSION}

State election codes limiting political speech have always existed in an uneasy harmony with the First Amendment. While McIntyre confirmed that anonymous political speech is entitled to First Amendment protection, it failed to delineate clearly the boundaries of permissible state regulation of election-related speech. Lower courts and state election boards must continue to sift through the Court's language, comparing challenged provisions to the statutes reviewed in Talley, Buckley, and now McIntyre.

This Comment has attempted to provide a general framework for post-McIntyre reviews of state disclosure statutes by drawing distinctions between types of political speech. Two prominent distinctions are consistent with McIntyre. First, broadcast speech can be more closely regulated than print speech. Disclosure statutes fulfill the First Amendment goal-recognized in the Court's communications jurisprudence- of using the broadcast medium to facilitate self-governance. Second, candidate speech should be distinguished from other political speech. The state can claim a stronger informational interest in regulating candidate speech, and speakers have weaker privacy interests in that context. Under McIntyre's reasoning, broadcast speech by candidates for public office bears greater similarity to Buckley speech than to Talley speech - and accordingly lacks any entitlement to anonymity. Courts should therefore uphold state disclosure statutes that are confined to broadcast communications by political candidates. 
